\title{
PERBANDINGAN HAK PENDIDIKAN DALAM KONSTITUSI NEGARA INDONESIA DENGAN KONSTITUSI BEBERAPA NEGARA DI ASIA TENGGARA
}

\section{COMPARISON OF EDUCATIONAL RIGHTS IN THE CONSTITUTION OF THE INDONESIAN STATE WITH THE CONSTITUTIONS OF SEVERAL COUNTRIES IN SOUTHEAST ASIA}

\author{
Dede \\ Program Pascasarjana Ilmu Hukum, Fakultas Hukum \\ Universitas Indonesia \\ dede.htn.pagi@gmail.com
}

\begin{abstract}
The constitution as the basis of a country contains various kinds of human rights, one of which is the right to education, the purpose of this research is to find out the reasons for the need for the right to education regulated in the constitution and to compare the rights of education in the Constitution of the Republic of Indonesia with several countries in Southeast Asia such as Singapore and Malaysia. The form of this research is Normative Juridical using a comparative approach. This research focuses on examining positive legal norms related to the right to education. The results of this study show that the comparative education rights of the Singaporean and Malaysian State Constitutions are more comprehensive in the Indonesian constitution. With this comparison, it can be seen the regulation of the right to education of each country so that it can provide input for amending the more equitable 1945 Constitution.
\end{abstract}

Keywords: comparison, constitution, education rights.

\section{Abstrak}

Konstitusi sebagai dasar suatu negara memuat berbagai macam hak asasi manusia salah satunya hak atas pendidikan, tujuan penelitian ini yaitu untuk mengetahui alasan perlunya hak atas pendidikan diatur dalam konstitusi serta untuk mengetahui perbandingan hak pendidikan dalam Konstitusi Negara Republik Indonesia dengan beberapa negara di Asia Tenggara seperti Singapura dan Malaysia. Bentuk penelitian ini yaitu Yuridis Normatif menggunakan pendekatan komparasi. Penelitian ini fokus pada penelaahan terhadap norma hukum positif yang berkaiatan dengan hak pendidikan. Hasil penelitian ini menunjukkan perbandingan hak pendidikan Konsitusi Negara Singapura dan Malaysia menurut penulis lebih komprehensif dalam konstitusi negara Indonesia. Dengan perbandingan tersebut, maka dapat diketahui pengaturan hak atas pendidikan dari masingmasing negara sehingga dapat memberikan masukan guna amandemen UUD 1945 yang lebih berkeadilan.

Kata Kunci: hak hendidikan, konstitusi, perbandingan.

\section{PENDAHULUAN}

Masalah pendidikan seyogianya memang harus diatur di dalam konstitusi, karena pendidikan merupakan bagian dari hak asasi yang mutlak dijamin oleh negara. Selain itu, dengan pendidikan dapat mendorong peningkatan sumber daya manusia ke arah pemajuan (promote) suatu bangsa. Jika suatu bangsa menguasai ilmu pengetahuan dan teknologi maka akan menjadikan bangsa tersebut menjadi bangsa yang mandiri dan tidak bergantung pada negara lain. Indonesia 
sebagai negara yang memiliki sumber daya alam yang sangat melimpah jika dibarengi dengan sumber daya manusia yang berkualitas maka tentu dapat menjadikan negara Indonesia sebagai negara yang memiliki kemajuan yang sangat pesat.

Itulah sebabnya ketika bom atom dijatuhkan di Hiroshima dan Nagasaki pada perang dunia II, Kaisar Hirohito tidak mencari balatentara untuk melanjutkan perang dunia II, tetapi ia berkata:" masih adakah guru yang tersisa".

Pendidikan merupakan suatu proses yang diperlukan untuk mendapatkan keseimbangan dan kesempurnaan dalam perkembangan individu maupun masyarakat. Penekanan pendidikan dibanding dengan pengajaran terletak pada pembentukan kesadaran dan kepribadian individu atau masyarakat di samping transfer ilmu dan keahlian. Dengan proses semacam ini suatu bangsa atau negara dapat mewariskan nilainilai keagamaan, kebudayaan, pemikiran dan keahlian kepada generasi berikutnya, sehingga mereka betul-betul siap menyongsong masa depan kehidupan bangsa dan negara yang lebih cerah [1].

Masyarakat dan pemerintah suatu negara berupaya untuk menjamin kelangsungan hidup serta kehidupan generasi penerusnya secara berguna (berkaitan dengan kemampuan spiritual) dan bermakna (berkaitan dengan kemampuan kognitif, afektif, dan psikomotor). Generasi penerus tersebut diharapkan akan mampu mengantisipasi hari depan mereka yang senantiasa merubah dan selalu terkait dengan konteks dinamika budaya, bangsa, negara, dan hubungan internasional. Semua itu tidak lain dilalui melalui pendidikan baik itu formal maupun non formal [2].

Dari latar bekang di atas maka penulis tertarik untuk mengangkat judul perbandingan hak pendidikan dalam konstitusi negara Indonesia dengan konstitusi beberapa negara di asia tenggara.

\section{METODE PENELITIAN}

Bentuk penelitian ini yaitu Yuridis Normatif. Penelitian ini berfokus pada penelaahan terhadap norma hukum positif berupa konstitusi yang berkaiatan dengan hak pendidikan. Dalam penelitian ini menggunakan pendekatan komparasi (Comparative Approach) yaitu dengan membandingkan antara Konstitusi Negara Indonesia dengan Negara Singapura dan Negara Malaysia

\section{PEMBAHASAN}

\section{Perlunya Pengaturan Hak Pendidikan di dalam Konstitusi}

Kemajuan suatu bangsa di masa sekarang dan masa datang akan sangat ditentukan generasi muda yang akan menjadi penerus bangsa itu sendiri. Generasi muda yang berkualitas dihasilkan dari adanya sistem pendidikan yang berkualitas pula. Tidak mungkin akselerasi kemajuan bangsa dapat terwujud di masa datang tanpa didukung oleh kemajuan di bidang pendidikan. Pendidikan merupakan investasi jangka panjang yang sangat berharga dan bernilai luhur, terutama bagi generasi muda yang akan menentukan maju mundurnya suatu bangsa[3].

Jika suatu bangsa ingin menjadi bangsa yang maju maka salah satu yang dapat dilakukan yaitu dengan meningkatkan kualitas pendidikannya. Allah SWT berfirman dalam Al-qur'an:

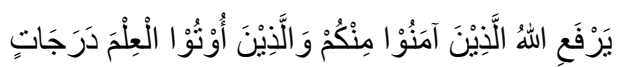

"Artinya: Allah akan meninggikan orangorang yang beriman di antaramu dan orangorang yang diberi ilmu pengetahuan beberapa derajat" [4].

Dalam ayat tersebut dijelaskan bahwa Allah SWT akan meningkatkan dengan beberapa derajat orang yang beriman dan berilmu, terkait dengan cara memperoleh ilmu maka dilakukan dengan pendidikan, untuk itu hak untuk memperoleh pendidikan harus diakui dalam suatu negara.

Selain daripada itu patut dicatat bahwa hak atas pendidikan merupakan salah satu 
hak asasi manusia yang bersifat universal sebagaimana diatur dalam pasal 26 Universal Declaration of Human Rights yang ketentuannya adalah sebagai berikut :

1. Everyone has the right to education. Education shall be free, at least in the elementary and fundamental stages. Elementary education shall be compulsory. Technical and professional education shall be made generally available and higher education shall be equally accessible to all on the basis of merit.

2. Education shall be directed to the full development of the human personality and to the strengthening of respect for human rights and fundamental freedoms. It shall promote understanding, tolerance and friendship among all nations, racial or religious groups, and shall further the activities of the United Nations for the maintenance of peace.

3. Parents have a prior right to choose the kind of education that shall be given to their children [5].

Dalam ketentuan tersebut maka jelas bahwa pendidikan merupakan salah satu bagian dari hak asasi manusia yang tentunya harus dijamin oleh suatu negara yaitu dengan mengakui hak pendidikan tersebut dalam konstitusi.

Bangsa Indonesia memahami bahwa "The Universal Declaration of Human Rights" yang dicetuskan pada tahun 1948 merupakan pernyataan umat manusia yang mengandung nilai-nilai universal yang wajib dihormati. Bersamaan dengan itu, bangsa Indonesia juga memandang bahwa "The Universal Declaration of Human Responsibility" yang dicetuskan oleh InterAction Council pada tahun 1997 juga mengandung nilai universal yang wajib dijunjung tinggi untuk melengkapi "The Universal Declaration of Human Rights" tersebut. Kesadaran umum mengenai hakhak dan kewajiban asasi manusia itu menjiwai keseluruhan sistem hukum dan konstitusi Indonesia, dan karena itu, perlu diadopsikan ke dalam rumusan UndangUndang Dasar atas dasar pengertianpengertian dasar yang dikembangkan sendiri oleh bangsa Indonesia. Karena itu, perumusannya dalam Undang-Undang Dasar ini mencakup warisan-warisan pemikiran mengenai hak asasi manusia di masa lalu dan mencakup pula pemikiran-pemikiran yang masih terus akan berkembang di masamasa yang akan datang [6].

Perbandingan Hak Pendidikan dalam Konstitusi Negara Indonesia dengan Konstitusi Beberapa Negara di Asia Tenggara.

Dalam tulisan ini penulis akan memperbandingkan hak pendidikan dalam konstitusi Negara Indonesia dengan Konstitusi Beberapa Negara di Asia tenggara yang meliputi Negara Malaysia dan Singapura.

\section{Perbandingan}

a. Hak pendidikan dalam Konstitusi Negara Indonesia

Undang-Undang Dasar 1945 telah mengatur secara eksplisit mengenai hak pendidikan yang diatur kedalam beberapa pasal misalnya dalam pasal $28 \mathrm{C}$ ayat (1) UUD 1945 menyatakan "Setiap orang berhak mengembangkan diri melalui pemenuhan kebutuhan dasarnya, berhak mendapat pendidikan dan memperoleh manfaat dari ilmu pengetahuan dan teknologi, seni dan budaya, demi meningkatkan kualitas hidupnya dan demi kesejahteraan umat manusia." [7]. Dari ketentuan tersebut maka dapat diketahui bahwa pendidikan itu merupakan hak setiap orang, untuk itu setiap orang berhak memilih pendidikan dan pengajaran, terkait hak memilih pendidikan diatur dalam Pasal 28E ayat (1) UUD 1945 yang menyatakan "Setiap orang berhak memeluk agama dan beribadat menurut agamanya, memilih pendidikan dan pengajaran, memilih pekerjaan, memilih kewarganegaraan, 
memilih tempat tinggal di wilayah negara dan meninggalkannya, serta berhak kembali" [7]. Dari ketentuan pasal tersebut maka dalam hal pemenuhan hak pendidikan sebenarnya tidak ada paksaan, artinya setiap orang berhak untuk memperoleh pendidikan sesuai dengan pilihannya.

Referensi [7] Pasal 31 ayat (1) UUD 1945 juga menyatakan "Setiap warga negara berhak mendapat pendidikan". [Namun terkait hak, pendidikan ini juga merupakan kewajiban sebagimana ditentukan dalam Pasal 31 ayat (2) UUD 1945 yang menentukan "Setiap warga negara wajib mengikuti pendidikan dasar dan pemerintah wajib membiayainya".

Pemerintah wajib membiayainya maka negara mengalokasikan anggaran untuk pendidikan Sekurangkurangnya dua luluh persen dari APBN sebagaimana ditentukan dalam pasal 31 ayat (4) UUD 1945 yang menentukan "Negara memprioritaskan anggaran pendidikan sekurang-kurangnya dua puluh persen dari anggaran pendapatan dan belanja negara serta dari anggaran pendapatan dan belanja daerah untuk memenuhi kebutuhan penyelenggaraan pendidikan nasional [7]."

b. Hak Pendidikan dalam Konstitusi Negara Singapura

Dalam Konstitusi Negara Singapura terkait pendidikan diatur dalam Part IV Fundamental Liberties dibagian Rights in respect of education yang ketentuannya sebagai berikut:

Article 16 menentukan sebagai berikut:

(1) Without prejudice to the generality of Article 12, there shall be no discrimination against any citizen of Singapore on the grounds only of religion, race, descent or place of birth

(a) in the administration of any educational institution maintained by a public authority, and, in particular, the admission of pupils or students or the payment of fees; or

(b) in providing out of the funds of a public authority financial aid for the maintenance or education of pupils or students in any educational institution (whether or not maintained by a public authority and whether within or outside Singapore).

(2) Every religious group has the right to establish and maintain institutions for the education of children and provide therein instruction in its own religion, and there shall be no discrimination on the ground only of religion in any law relating to such institutions or in the administration of any such law [8].

Dari ketentuan tersebut menurut penulis ada hal menarik dari Kostitusi Negara Singapura. Di Negara Singapura memberi hak pendidikan yang dituangkan dalam konstitusi terhadap setiap kelompok agama untuk mendirikan dan memelihara lembaga pendidikan untuk anak-anak dan memberikan instruksi di dalamnya dalam agamanya sendiri.

Selanjutnya dalam article 152 paragraph (2) menentukan sebagai berikut :

"The Government shall exercise its functions in such manner as to recognise the special position of the Malays, who are the indigenous 
people of Singapore, and accordingly it shall be the responsibility of the Government to protect, safeguard, support, foster and promote their political, educational, religious, economic, social and cultural interests and the Malay language [9]."

Dari ketentuan tersebut kita dapat mengetahui bahwa pemerintah harus bertanggungjawab untuk melindungi, menjaga, membina dan mempromosikan kepentingan pendidikan. Tentunya ketentuan tersebut dalam rangka supaya hak pendidikan di negara tersebut dapat terlindungi dan terealisasi.

c. Hak Pendidikan dalam Konstitusi Negara Malaysia.

Di dalam Konstitusi Negara Malaysia mengenai dasar hukum terkait pendidikan diatur dalam Article number: 12 yang ketentuannya mirip dengan Konstitusi Negara Singapura. Adapun ketentuannya adalah sebagai berikut : Article number: 12

(1) Without prejudice to the generality of Article 8, there shall be no discrimination against any citizen on the grounds only of religion, race, descent or place of birth

(a) in the administration of any educational institution maintained by a public authority, and, in particular, the admission of pupils or students or the payment of fees; or

(b) in providing out of the funds of a public authority financial aid for the maintenance or education of pupils or students in any educational institution (whether or not maintained by a public authority and whether within or outside the Federation).

(2) Every religious group has the right to establish and maintain institutions for the education of children in its own religion, and there shall be no discrimination on the ground only of religion in any law relating to such institutions or in the administration of any such law; but it shall be lawful for the Federation or a State to establish or maintain or assist in establishing or maintaining Islamic institutions or provide or assist in providing instruction in the religion of Islam and incur such expenditure as may be necessary for the purpose[10].

Konstitusi Negara Malaysia sama halnya dengan Konstitusi Negara Singapura, dalam hak pendidikan setiap kelompok agama berhak untuk mendirikan dan memelihara lembaga pendidikan untuk anak-anak menurut agamanya sendiri.

Menurut penulis dari Konstitusi Negara Singapura maupun Malaysia jika dikaitkan dengan kondisi di negara Indonesia, perlu juga diatur mengenai hak pendidikan untuk setiap kelompok agama dalam mendirikan dan memelihara lembaga pendidikan untuk anak-anak menurut agamanya sendiri. Dengan diaturnya ketentuan tersebut maka pesantren ataupun lembaga pendidikan lainnya lebih terlegitimasi.

\section{Analisis Perbandingan}

Menurut penulis dari perbandingan tersebut, Konstitusi Negara Indonesia telah mengatur luas terkait pendidikan, 
mulai dari hak setiap orang untuk mendapatkan pendidikan, memilih pendidikan, kewajiban warga negara untuk mengikuti pendidikan, kewajiban pemerintah untuk membiayai pendidikan bahkan alokasi anggaran pendidikan ditentukan dalam konstitusi. Bahkan jika dibandingkan dengan Konsitusi Negara Singapura maupun Malaysia menurut penulis lebih komprehensif pengaturan terkait hak pendidikan dalam konstitusi negara Indonesia. Namun ada hal lain yang diatur dalam Konstitusi Negara Singapura dan Malaysia yang mana keduanya dalam hak pendidikan mengatur juga hak untuk setiap kelompok agama untuk mendirikan dan memelihara lembaga pendidikan untuk anak-anak menurut agamanya sendiri, menurut penulis dengan melihat kondisi Negara Indonesia yang terdiri dari beragam agama dan dengan banyaknya lembaga pendidikan seperti pesantren dan lain-lain, harusnya konstitusi indonesia menambah ketentuan mengenai hak pendidikan untuk setiap kelompok agama dalam mendirikan dan memelihara lembaga pendidikan untuk anak-anak menurut agamanya sendiri.

\section{KESIMPULAN}

Dari perbandingan tersebut, Konstitusi Negara Indonesia telah mengatur luas terkait pendidikan, mulai dari hak setiap orang untuk mendapatkan pendidikan, memilih pendidikan, kewajiban warga negara untuk mengikuti pendidikan, kewajiban pemerintah untuk membiayai pendidikan bahkan alokasi anggaran pendidikan ditentukan dalam konstitusi. Jika dibandingkan dengan Konsitusi Negara Singapura maupun Malaysia menurut penulis lebih komprehensif pengaturan terkait hak pendidikan dalam konstitusi negara Indonesia. Namun ada hal lain yang diatur dalam Konstitusi Negara Singapura dan Malaysia yang mana keduanya dalam hak pendidikan mengatur juga hak untuk setiap kelompok agama untuk mendirikan dan memelihara lembaga pendidikan untuk anak-anak menurut agamanya sendiri, menurut penulis dengan melihat kondisi Negara Indonesia yang terdiri dari beragam agama dan dengan banyaknya lembaga pendidikan seperti pesantren dan lain-lain, harusnya konstitusi indonesia menambah ketentuan mengenai hak pendidikan untuk setiap kelompok agama dalam mendirikan dan memelihara lembaga pendidikan untuk anak-anak menurut agamanya sendiri.

\section{DAFTAR PUSTAKA}

[1]. Nurkholis. (2013). Pendidikan Dalam Upaya Memajukan Teknologi. Jurnal Kependidikan, 1(1).

[2]. Dina Indriyani. (2017). Hak Asasi Manusia Dalam Memperoleh Pendidikan, 7(8).

[3]. Muhardi. (2004). Kontribusi Pendidikan Dalam Meningkatkan Kualitas Bangsa Indonesia, 20(4).

[4]. Al-Qur'an, Surat Al-Mujadalah, Ayat 11.

[5]. Universal Declaration of Human Rights, article 26.

[6]. Asshiddiqie, Jimly. (2006). Konstitusi dan Konstitusionalisme. Jakarta : Sekretariat Jenderal dan Kepaniteraan MK RI. (Hal. 90)

[7]. Majelis Permusyawaratan Rakyat Republik Indonesia. (2002). Undang-Undang Dasar Negara Republik Indonesia Tahun 1945. Jakarta: Sekretariat Jenderal MPR RI.

[8]. Constitution Of The Republic Of Singapore. Article 16 paragraph (1) and (2)

[9]. Constitution of The Republic Of Singapore. Article 152 paragraph (2)

[10]. Constitution of Malaysia. Article 12 
